\title{
Porous concrete basic property criteria as rigid pavement base layer adjusting field gradation
}

\author{
Frisky Ridwan Aldila Melania Care ${ }^{1, *}$, Bambang Sugeng Subagio ${ }^{1}$, Harmein Rahman $^{1}$, and R. Anwar Yamin ${ }^{2}$ \\ ${ }^{1}$ Faculty of Civil Engineering and Environment, Institut Teknologi Bandung, 40132 Bandung, Indonesia \\ ${ }^{2}$ Centre of Research and Development for Roads and Bridges, Ministry of Public Works and Housing, Bandung, Indonesia
}

\begin{abstract}
Porous concrete has been widely used for many purposes in this couple of days. In reality, it might be difficult to create an ideal uniform graded porous concrete mixture proportion with the field gradation circumstances. The aim of this study was to find a porous concrete mixdesign proportion that could adjust field gradation and meet Specifications requirements by utilizing continuous graded aggregate. Compressive strength and vertical permeability produced by porous concrete using continuous graded aggregate stayed above the minimum limit for base layer required by Specifications. Continuous graded porous concrete from mix-design variation II produced higher compressive strength, but lower void content and vertical permeability compared to mix design variation I at the age of 28-days. It was found that continuous graded porous concrete from both mix-design variations had an optimum basic parameters in specific value as well. Porous concrete that adjust the field gradation gave a better basic property criteria compared to ideal gradation. The relationship between void content and vertical permeability from continuous graded porous concrete had a similar behavior with uniform graded porous concrete. Overall, the use of continuous graded porous concrete would be very helpful in Indonesia because it can adjust the gradation on the field.
\end{abstract}

\section{Introduction}

Porous concrete has been widely used for many purposes in this couple of days, especially in the developed country. In pavement application, porous concrete may be used as a surface course for parking lots and low volume roads because of its limited strength. ACI Committee 522 [1] reported that porous concrete generally has a low compressive strength value, ranging from $2.8 \mathrm{MPa}-28$ $\mathrm{MPa}$, when compared to normal concrete. In exchange, the high void content which ranging from $15 \%$ to $35 \%$ owned by this concrete gives it an ability to let water passing through into the ground. Because its compressive strength value still not fulfilling the minimum limit as a surface layer which required by Specification [2], it will be more realistic to place it as a base layer in rigid pavement structure in Indonesia.

Most of rigid pavement structures in Indonesia commonly utilize a base layer that contain grained materials. Base materials that contain large fine material tend to have a low permeability and slow water movement. The combination of trapped infiltration water and repeated traffic loading will create void below the surface layer and end up of erosion in pavement foundation. Erosion phenomenon could lead to the loss of foundation support, pavement premature distress and short-term service life issue [3].
Survey results related to rigid pavement distress that collected from several toll roads and highways in Indonesia showed that pumping, faulting and longitudinal cracking distress were very plentiful. These shorts of distress generally happened due to loss of foundation support, poor drainage and erosion problem in base layer [4]. Base layer with drainage ability like porous concrete was needed to handle those problems.

In reality, it might be difficult to create an ideal uniform graded porous concrete mixture proportion with the field gradation circumstances. Most of aggregates on the field usually consist of continuous graded aggregate with the range of specific size. Collecting uniform graded aggregate with a specific size could mean discarding the other size of aggregate. In developing country like Indonesia, an aggregate sieve instrument for such large aggregate composition is very limited. Moreover, the sieving process can increase the production fee as well so that some concrete distributors tend not to choose it as an alternative.

The aim of this study was to find a porous concrete mix-design proportion that could adjust field gradation and meet the Specifications requirements (see Table 1) by utilizing continuous graded aggregate. Previous research conducted by Goede [5] and McCain [6] showed that the used of uniform aggregate in porous concrete could produce compressive strength value up to $11.5 \mathrm{MPa}$ and

\footnotetext{
* Corresponding author: friskyramc@gmail.com
} 
vertical permeability value up to $1.2 \mathrm{~cm} / \mathrm{s}$. Care [7] mentioned that uniform graded porous concrete mixture could produce compressive strength up to $12.2 \mathrm{MPa}$ and vertical permeability up to $2.6 \mathrm{~cm} / \mathrm{s}$ as well. However, the prior research conducted by Arnoldus [8] showed that continuous graded porous concrete could produce a compressive strength up to $15.8 \mathrm{MPa}$ and vertical permeability up to $0.7 \mathrm{~cm} / \mathrm{s}$. This result indicated that the use of continuous graded aggregate in porous concrete could give an enhancement in its compressive strength. Continuous graded aggregate was chosen because it also had a fine potency to approach the gradation condition on the field.

Table 1. Rigid pavement base layer criteria [2,9]

\begin{tabular}{|c|c|c|}
\hline Base Layer Type & $\begin{array}{c}\text { Lean } \\
\text { Concrete }\end{array}$ & $\begin{array}{c}\text { Aggregate Class } \\
\text { A }\end{array}$ \\
\hline $\begin{array}{c}\text { Min. compressive } \\
\text { strength at 7-days } \\
(\mathrm{MPa})\end{array}$ & 6.4 & - \\
\hline $\begin{array}{c}\text { Min. compressive } \\
\text { strength at 28-days } \\
(\mathrm{MPa})\end{array}$ & 8.0 & - \\
\hline $\begin{array}{c}\text { Min. Permeability } \\
\text { value (cm/sec) }\end{array}$ & - & 0.1 \\
\hline
\end{tabular}

\section{Research methodology}

The laboratory study of porous concrete basic property criteria as rigid pavement base layer adjusting field gradation consists of following three main steps: (a) porous concrete mix-design proportion; (b) measurement of basic property criteria based on fresh density parameter, compressive strength parameter, void content parameter and permeability parameter; (c) Statistical correlation test between parameters. These three steps are described in detail in the following sub-sections. All of the material properties are tested based on American Society for Testing Material (ASTM).

\section{Mix-design proportion}

Porous concrete mixtures were designed using ACI Committee 522 standard [1] and some graphics from Meininger's [10] experimental test result. These mixtures consist of continuous graded aggregate, portland cement type I, water, HRWR, VMA and retarder. The chemical additive dosage was used based on Anderson's [11] experimental test result. Iron stick stabbing 25 times was used as compaction method [7]. Polyethylene bag curing method was conducted to gain optimum compressive strength [12]. The specimen for compressive strength test were cast into cylinders with diameter 6" and length 12" [13], whereas the specimen for void content and permeability test were cast into cylinders with diameter 5 " and length 5.24" [14]. All of porous concrete mix-design proportions in this research are listed in Table 4 and Table 5.
Table 2. Split aggregate sieve analysis result for mix-design variation I

\begin{tabular}{|c|c|c|c|}
\hline $\begin{array}{c}\text { Sieve } \\
\text { Size } \\
(\mathrm{mm})\end{array}$ & $\begin{array}{c}\text { Retained } \\
\text { Percentage }\end{array}$ & $\begin{array}{c}\text { Cumulative } \\
\text { Retained } \\
\text { Percentage }\end{array}$ & $\begin{array}{c}\text { Cumulative } \\
\text { Passing } \\
\text { Percentage }\end{array}$ \\
\hline 19,0 & $18 \%$ & $18 \%$ & $82 \%$ \\
\hline 12,7 & $44 \%$ & $61 \%$ & $39 \%$ \\
\hline 9.5 & $35 \%$ & $96 \%$ & $4 \%$ \\
\hline 4,75 & $4 \%$ & $100 \%$ & $0 \%$ \\
\hline 2,36 & $0 \%$ & $100 \%$ & $0 \%$ \\
\hline
\end{tabular}

Table 3. Split aggregate sieve analysis result for mix-design variation II

\begin{tabular}{|c|c|c|c|}
\hline $\begin{array}{c}\text { Sieve } \\
\text { Size } \\
(\mathrm{mm})\end{array}$ & $\begin{array}{c}\text { Retained } \\
\text { Percentage }\end{array}$ & $\begin{array}{c}\text { Cumulative } \\
\text { Retained } \\
\text { Percentage }\end{array}$ & $\begin{array}{c}\text { Cumulative } \\
\text { Passing } \\
\text { Percentage }\end{array}$ \\
\hline 19,0 & $21 \%$ & $21 \%$ & $79 \%$ \\
\hline 12,7 & $38 \%$ & $58 \%$ & $42 \%$ \\
\hline 9.5 & $23 \%$ & $82 \%$ & $18 \%$ \\
\hline 4,75 & $15 \%$ & $97 \%$ & $3 \%$ \\
\hline 2,36 & $3 \%$ & $100 \%$ & $0 \%$ \\
\hline
\end{tabular}

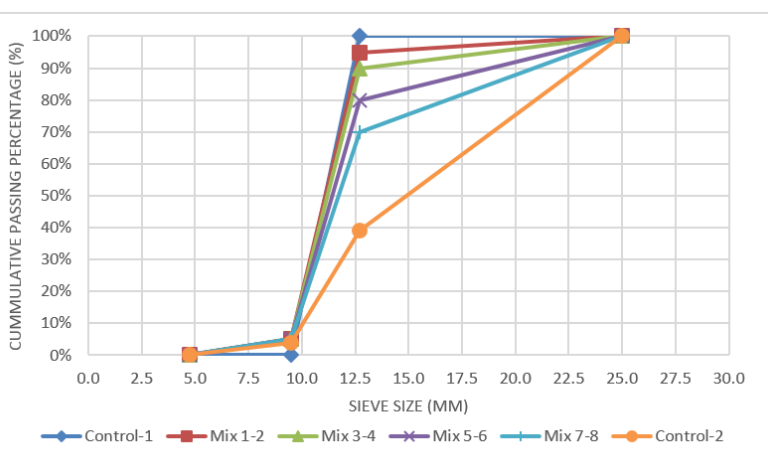

Fig. 1. Aggregate gradation I that used in mix-design var-I.

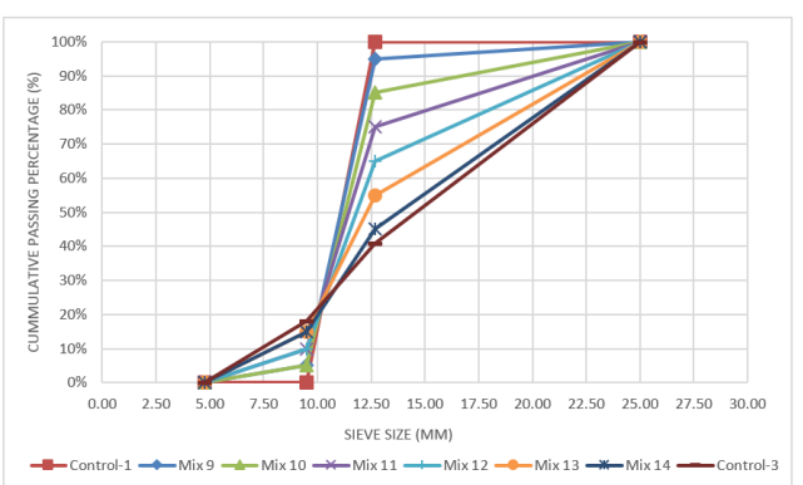

Fig. 2. Aggregate gradation II that used in mix-design var-II.

The amount of aggregate percentage from split aggregate gradation analysis results were utilized to adjust the field gradation of aggregate. In sieve aggregate analysis result for mix-design variation I, aggregate percentage that passing sieve $12.7 \mathrm{~mm}$ as much as $39 \%$ and sieve $9.5 \mathrm{~mm}$ as much as $4 \%$ (see Table 2) were used as control-2 to simulate maximum gradation condition on the field. In sieve aggregate analysis result for mix-design 
variation II, aggregate percentage that passing sieve 12.7 $\mathrm{mm}$ as much as $42 \%$ and sieve $9.5 \mathrm{~mm}$ as much as $18 \%$ (see Table 3) were used as control-3 to simulate maximum gradation condition on the field. Size $9.5 \mathrm{~mm}$ was used as control-1 to act as an ideal gradation condition because it gave maximum vertical permeability value and more uniform void content dispersion compared to size $19.0 \mathrm{~mm}$ and $12.7 \mathrm{~mm}$ (Care [9]). Aggregate gradation I (see Fig. 1) and aggregate gradation II (see Fig. 2) had different sieve analysis result because both of them were not taken in the same time from the quarry so that two types of mix-design variation would be used as field gradation simulation. The proportion of porous concrete mix-design variation I (see Table 4) was arranged based on control-1 and control-2 and it only varies the percentage of size $19.0 \mathrm{~mm}-12.7$ $\mathrm{mm}$ and $9.5 \mathrm{~mm}$, whereas mix-design variation II (see Table 5) was arranged based on control-1 and control-3 and it varies the percentage of all sizes, i.e. size $19.0 \mathrm{~mm}$ $-12.7 \mathrm{~mm}, 9.5 \mathrm{~mm}$ and $4.75 \mathrm{~mm}-2.36 \mathrm{~mm}$.

Table 4. Porous concrete mix-design proportion using aggregate gradation I ( $1 \mathrm{~m}^{3}$ concrete)

\begin{tabular}{|c|c|c|c|}
\hline $\begin{array}{c}\text { Mix. } \\
\text { Number }\end{array}$ & $\begin{array}{c}\text { Aggregate Size } \\
19.0 \mathrm{~mm}-12.7 \\
\mathrm{~mm} \text { (retained) }\end{array}$ & $\begin{array}{c}\text { Aggregate Size } \\
9.5 \mathrm{~mm} \\
\text { (retained) }\end{array}$ & $\begin{array}{c}\text { Aggregate Size } \\
4.75 \mathrm{~mm}-2.36 \\
\mathrm{~mm} \text { (retained) }\end{array}$ \\
\hline 1 & $5 \%$ & $90 \%$ & $5 \%$ \\
\hline 2 & $5 \%$ & $90 \%$ & $5 \%$ \\
\hline 3 & $10 \%$ & $85 \%$ & $5 \%$ \\
\hline 4 & $10 \%$ & $85 \%$ & $5 \%$ \\
\hline 5 & $20 \%$ & $75 \%$ & $5 \%$ \\
\hline 6 & $20 \%$ & $75 \%$ & $5 \%$ \\
\hline 7 & $30 \%$ & $65 \%$ & $5 \%$ \\
\hline 8 & $30 \%$ & $65 \%$ & $5 \%$ \\
\hline
\end{tabular}

all mixtures used water cement ratio 0.30 ; aggregate cement ratio 4.0; HRWR $2 \mathrm{~mL}$; Retarder $6 \mathrm{~mL}$; VMA $6 \mathrm{~mL}$ curing time 7 -days; curing time 28 -days

Table 5. Porous concrete mix-design proportion using aggregate gradation II ( $1 \mathrm{~m}^{3}$ concrete)

\begin{tabular}{|c|c|c|c|}
\hline $\begin{array}{c}\text { Mix. } \\
\text { Number }\end{array}$ & $\begin{array}{c}\text { Aggregate Size } \\
19.0 \mathrm{~mm}-12.7 \\
\text { mm (retained) }\end{array}$ & $\begin{array}{c}\text { Aggregate Size } \\
9.5 \mathrm{~mm} \\
\text { (retained) }\end{array}$ & $\begin{array}{c}\text { Aggregate Size } \\
4.75 \mathrm{~mm}-2.36 \\
\text { mm (retained) }\end{array}$ \\
\hline 9 & $5 \%$ & $90 \%$ & $5 \%$ \\
\hline 10 & $15 \%$ & $80 \%$ & $5 \%$ \\
\hline 11 & $25 \%$ & $65 \%$ & $10 \%$ \\
\hline 12 & $35 \%$ & $55 \%$ & $10 \%$ \\
\hline 13 & $45 \%$ & $40 \%$ & $15 \%$ \\
\hline 14 & $55 \%$ & $30 \%$ & $15 \%$ \\
\hline
\end{tabular}

all mixtures used water cement ratio 0.30 ; aggregate cement ratio 4.0; HRWR $2 \mathrm{~mL}$; Retarder $6 \mathrm{~mL}$; VMA $6 \mathrm{~mL}$ curing time 28 -days

\section{Measurement of basic property criteria}

Four basic parameters were applied to represent the required criteria for rigid pavement base layer: (1) fresh density; (2) compressive strength; (3) void content; (4) vertical permeability. All of the explanation about the variable in the equations are attached below the equation along with their units.

Fresh density describes the density of freshly mixed porous concrete. The test was conducted in accordance with ASTM C-1688 [15] and calculated using formula:

$$
D=\frac{M_{c}-M_{m}}{V_{m}}
$$

Where $D$ is density of concrete $\left(\mathrm{kg} / \mathrm{m}^{3}\right), M_{c}$ is mass of the measure filled with concrete $(\mathrm{kg}), M_{m}$ is mass of the measure $(\mathrm{kg}), V_{m}$ is volume of the measure $\left(\mathrm{m}^{3}\right)$.

Compressive Strength $\left(\mathrm{f}^{\prime}{ }_{\mathrm{c}}\right)$ describes the typical concrete ability to receive compressive force per unit area. The compressive strength test was conducted in accordance with ASTM C-39 [13] and calculated using formula:

$$
f^{\prime} c=\frac{F}{A}
$$

Where $f_{c}^{\prime}$ is compressive strength $(\mathrm{MPa}), F$ is maximum compressive force $(\mathrm{N}), A$ is cross-sectional area of the specimen $\left(\mathrm{m}^{2}\right)$.

Void content describes the total open space within the porous concrete. It is a comparison of the volume of voids, to the total volume of cement paste and aggregate. The void content test was conducted in accordance with ASTM C-1754 [16] and calculated using formula:

$$
V_{r}=\left[1-\left(\frac{M_{w}-M_{d}}{\rho_{w} \times V o l}\right)\right]
$$

Where $V_{r}$ is void content (\%), $M_{w}$ is specimen mass in water $(\mathrm{kg}), M_{d}$ is dry specimen mass $(\mathrm{kg}), P_{w}$ is density of water $\left(\mathrm{kg} / \mathrm{m}^{3}\right)$ and $V_{o l}$ is volume of specimen $\left(\mathrm{m}^{3}\right)$.

Permeability describes the easiness of concrete to be penetrated or passed by liquid or gas. Normally, the material permeability is indicated by its hydraulic conductivity or permeability value. Darcy's Law defines hydraulic conductivity as the ratio of fluid average velocity that passing through a transverse area against applied hydraulic gradient. The test was conducted using modified falling head permeameter apparatus which developed by McCain [6]. Montes [17] showed that under these head values laminar flow conditions are expected to exist in pervious concrete pavement and Darcy's law can be used to determine the hydraulic conductivity. The permeability test was conducted in accordance with ASTM D-5084 [14] and calculated using formula:

$$
k=\frac{a \cdot L}{A \cdot t} \ln \left(\frac{h_{1}}{h_{2}}\right)
$$

Where $k$ is vertical permeability coefficient $(\mathrm{m} / \mathrm{s}), a$ is cross-sectional area of the standpipe $\left(\mathrm{m}^{2}\right), L$ is length of the specimen $(\mathrm{m}), A$ is cross-sectional area of the specimen $\left(\mathrm{m}^{2}\right), t$ is time for water to drop from $h_{1}$ to $h_{2}(\mathrm{~s})$, $h_{l}$ is initial water level (m) and $h_{2}$ is final water level (m).

\section{Statistical correlation test}

The correlation between the basic design parameters was described using simple correlation test. This test is a 
statistical technique which is used to measure the relationship level between 2 variables and the shape of their relationship. The relationship level is stated in number wherein bigger number shows stronger relationship. The simple correlation test was computed utilizing formula:

$$
R^{2}=\frac{\sum X Y}{\sqrt{\sum X^{2} \sum Y^{2}}}
$$

Where $R^{2}$ is simple correlation coefficient, $X$ is independent variable and $Y$ is dependent variable.

\section{Basic property test result}

This section covers the result of basic design parameter. Several discussions were attached as well to illustrate the laboratory test result.

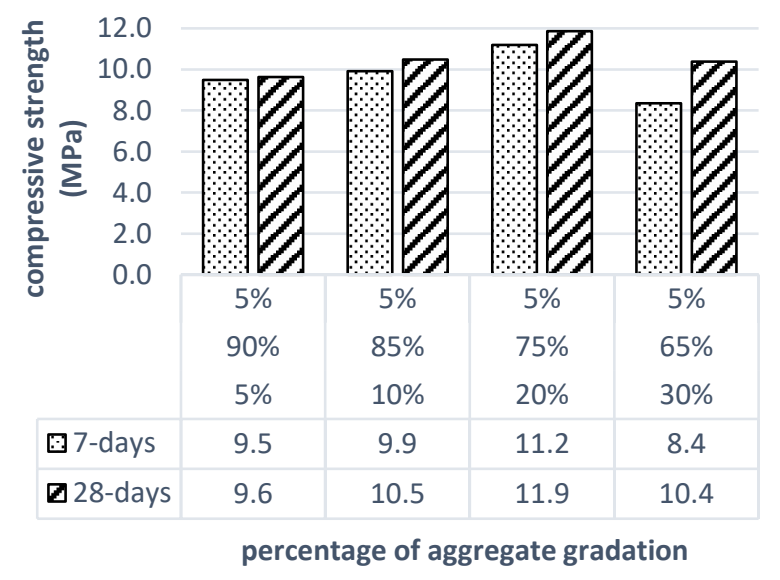

void content range: $26.8 \%-32.5 \%$

vertical permeability range: $1.4 \mathrm{~cm} / \mathrm{sec}-3.2 \mathrm{~cm} / \mathrm{sec}$

Fig. 3. Relationship between field gradation variation I and compressive strength.

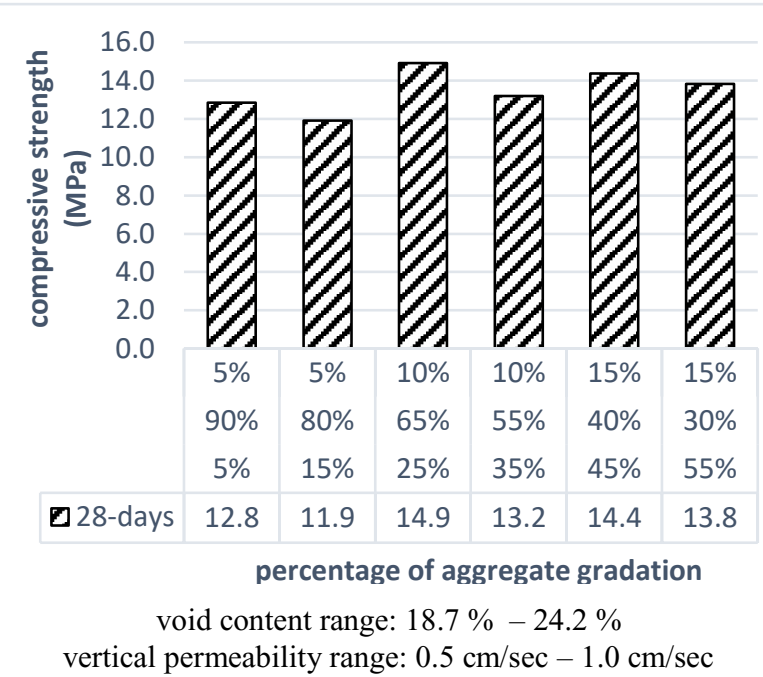

Fig. 4. Relationship between field gradation variation II and compressive strength.

Porous concrete that contain continuous graded aggregate possessed low possibility to improve its compressive strength from age 7-days to 28-days. Based on Fig. 3, continuous graded porous concrete that contain size $9.5 \mathrm{~mm}$ until $75 \%$ had a slight improvement in its compressive strength from the age of 7-days to 28-days. However, it had a significant improvement when the percentage of size $9.5 \mathrm{~mm}$ reach $65 \%$. When the percentage of size $9.5 \mathrm{~mm}$ ranged from $90 \%$ to $75 \%$, the bond between cement paste and aggregate in Interfacial Transition Zone (ITZ) plays important role to increase the strength. When the percentage of size $9.5 \mathrm{~mm}$ dropped to $65 \%$, the percentage of size $19.0 \mathrm{~mm}-12.7 \mathrm{~mm}$ might also grew to $30 \%$. This situation gave a chance for interlocking effect among aggregates inside the mixture to make a contribution to the strength as well. The combination between the bond in the ITZ and the interlocking effect created a significant improvement in the compressive strength. Moreover, all of compressive strength values from mix-design variation I had already surpassed the minimum limit for base layer, i.e. $8.0 \mathrm{MPa}$, required by Specification [2] at the age of 7-days.

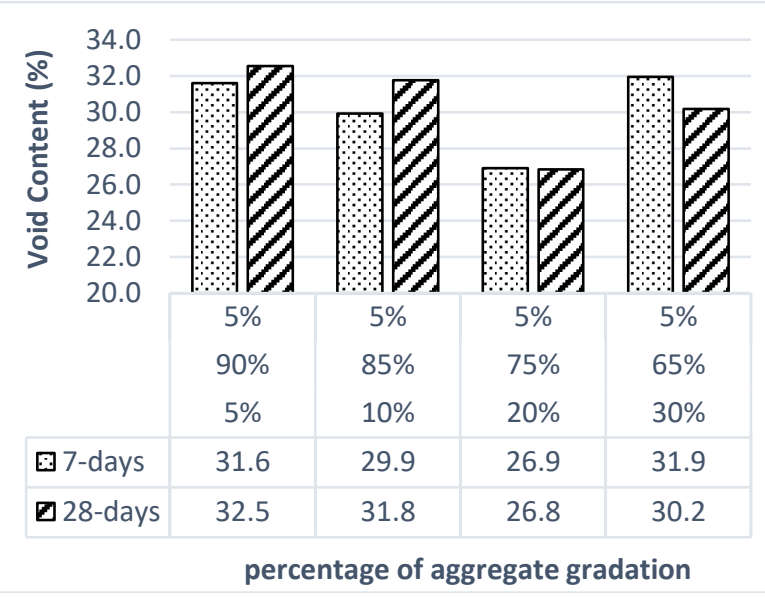

compressive strength range: $8.4 \mathrm{MPa}-11.9 \mathrm{MPa}$

vertical permeability range: $1.4 \mathrm{~cm} / \mathrm{sec}-3.2 \mathrm{~cm} / \mathrm{sec}$

Fig. 5. Relationship between field gradation variation I and void content.

Continuous graded porous concrete from mix-design variation II had a higher compressive strength than mix design variation I at the age of 28-days. As can be seen in Fig. 3 and Fig. 4, the compressive strength value from mix-design variation II ranged from 11.9 $\mathrm{MPa}$ to 14.9 $\mathrm{MPa}$, whereas the compressive strength value from mixdesign variation II ranged from 9.6 MPa to $11.9 \mathrm{MPa}$. This situation showed that the increase of size $4.75 \mathrm{~mm}-2.36$ $\mathrm{mm}$ percentage usage in mix-design variation II could make a better interlocking effect among the aggregates. The compressive strength value from all mixtures were stayed above the minimum limit, i.e. 8.0 MPa, for base layer required by Specification [2] at the age of 28-days. Porous concrete that contain continuous graded aggregate also owned an optimum compressive strength at the specific percentage. In optimum condition, the bond between cement paste and aggregate in Interfacial Transition Zone (ITZ) and aggregate interlocking effect created compound contribution for porous concrete's compressive strength. In addition, continuous graded porous concrete also produced a higher maximum 
compressive strength, i.e. $14.9 \mathrm{MPa}$, compared to uniform gradation with size $9.5 \mathrm{~mm}$, i.e. $12.2 \mathrm{MPa}$ that gained by Care [7].

Continuous graded porous concrete from mix-design variation I had an optimum void content in specific value at the age of 7-days and 28-days. There was a slight improvement in the void content from age 7-days to 28days when the percentage of size $9.5 \mathrm{~mm}$ was decreased until $85 \%$ (see Fig. 5). However, the improvement was not visible anymore when the percentage of size $9.5 \mathrm{~mm}$ was used below $85 \%$. The void content tend to be fell from age 7-days to age 28-days until $65 \%$ of size $9.5 \mathrm{~mm}$ was used. When the percentage of $9.5 \mathrm{~mm}$ was above $85 \%$, there was adequate cement paste amount to create a good covering thickness on the aggregate surface inside the mixture. The drop of size $9.5 \mathrm{~mm}$ percentage rose the percentage of size $19.0 \mathrm{~mm}-12.7 \mathrm{~mm}$ gradually so that the aggregate surface which must be covered by cement paste would be increased. When the percentage of size 9.5 mm was decreased until $65 \%$, the amount of cement paste that covering the aggregate surface became thinner and cause a reduction in void content as well. Moreover, all of void content values from mix-design variation I stayed above $20 \%$ wherein this condition was expected to maintain a high permeability during pavement design life in zero maintenance condition [18].

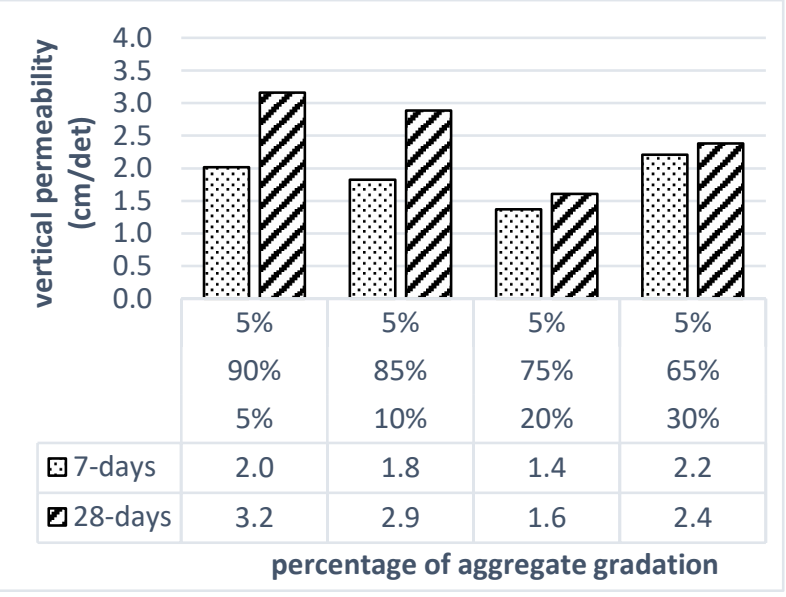

compressive strength range: $8.4 \mathrm{MPa}-11.9 \mathrm{MPa}$ void content range: $26.8 \%-32.5 \%$

Fig. 6. Relationship between field gradation variation I and vertical permeability

Continuous graded porous concrete from mix-design variation I also had an optimum vertical permeability in specific value at the age of 7-days and 28-days. Fig. 6 illustrates a significant improvement of vertical permeability from age 7-days to age 28-days when the percentage of size $9.5 \mathrm{~mm}$ was used until $85 \%$. However, the improvement switch into a slightly increase when the percentage of size $9.5 \mathrm{~mm}$ was used below $85 \%$. Porous concrete's vertical permeability had a direct relationship with its void content. When the void content increased gradually, the vertical permeability would increase significantly as well. On the contrary, the vertical permeability would increase slightly when the void content rose slowly. Additionally, all of vertical permeability values from mix design variation I stayed above the minimum limit of permeability, i.e. $0.1 \mathrm{~cm} / \mathrm{sec}$, for base layer required by Specification [9] at the age of 7-days and 28-days.

Continuous graded porous concrete from mix-design variation II had a lower averaged void content than mix design variation I at the age of 28-days. It possessed a lower optimum void content than mix-design variation I at the age of 28-days as well. In mix-design variation II, the void content ranged from $18.7 \%$ to $24.2 \%$ wherein its optimum void content was valued $18.7 \%$ and located in percentage $40 \%$ of size $9.5 \mathrm{~mm}$ (See Fig. 5). In mixdesign variation I, the void content ranged from $26.8 \%$ to $32.5 \%$ wherein its optimum void content was valued $26.8 \%$ and located in percentage $75 \%$ of size $9.5 \mathrm{~mm}$ (See Fig. 7). Dissimilar ratio between the amount of cement paste content and aggregate interlocking inside those mixtures produced a different optimum void content location. The decrease of size $9.5 \mathrm{~mm}$ percentage created a less chance for cement paste to fill the cavity inside the mixture. The decrease of cement paste amount also reduced the amount of void inside the mixture. On the contrary, the increase of size $19.0 \mathrm{~mm}-12.7 \mathrm{~mm}$ and size $6.7 \mathrm{~mm}$ and $4.75 \mathrm{~mm}$ created better interlocking among the aggregate inside the mixture. Different ratio between the amount of cement paste content and aggregate interlocking inside both mixtures created a different porous concrete optimum void content location. Only several void content values from mix-design variation II stayed above $20 \%$ wherein this condition was expected to maintain a high permeability during pavement design life in zero maintenance condition [18].

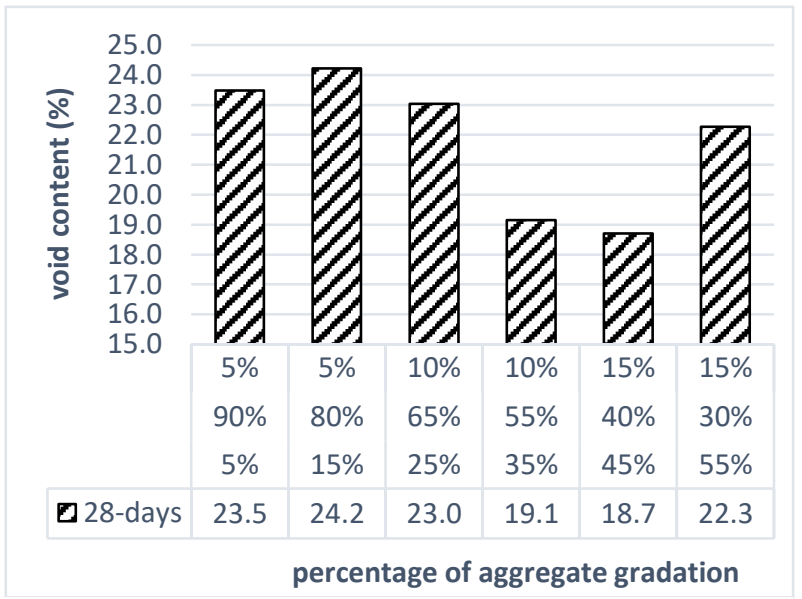

compressive strength range: $11.9 \mathrm{MPa}-14.9 \mathrm{MPa}$

vertical permeability range: $0.52 \mathrm{~cm} / \mathrm{sec}-0.98 \mathrm{~cm} / \mathrm{sec}$

Fig. 7. Relationship between field gradation variation II and void content.

Continuous graded porous concrete from mix-design variation II had a lower averaged vertical permeability than mix design variation $I$ at the age of 28 -days. It possessed a lower optimum vertical permeability than mix-design variation I at the age of 28-days as well. In mix-design variation II, the vertical permeability ranged from $0.5 \mathrm{~cm} / \mathrm{sec}$ to $1.0 \mathrm{~cm} / \mathrm{sec}$ wherein its optimum vertical permeability was valued $0.5 \mathrm{~cm} / \mathrm{sec}$ (See Fig. 8). In mix-design variation I, the void content ranged from $1.6 \mathrm{~cm} / \mathrm{sec}$ to $3.2 \mathrm{~cm} / \mathrm{sec}$ wherein its optimum void 
content was valued $1.6 \mathrm{~cm} / \mathrm{sec}$ (See Fig. 6). The increase and decrease of vertical permeability value at the age of 28 -days walked the same way with its void content value at the age of 28-days. Although only several void content values stayed above $20 \%$, whole vertical permeability values from mix design variation II stayed above the minimum limit of permeability, i.e. $0.1 \mathrm{~cm} / \mathrm{sec}$, for base layer required by Specification [9] at the age of 28-days.

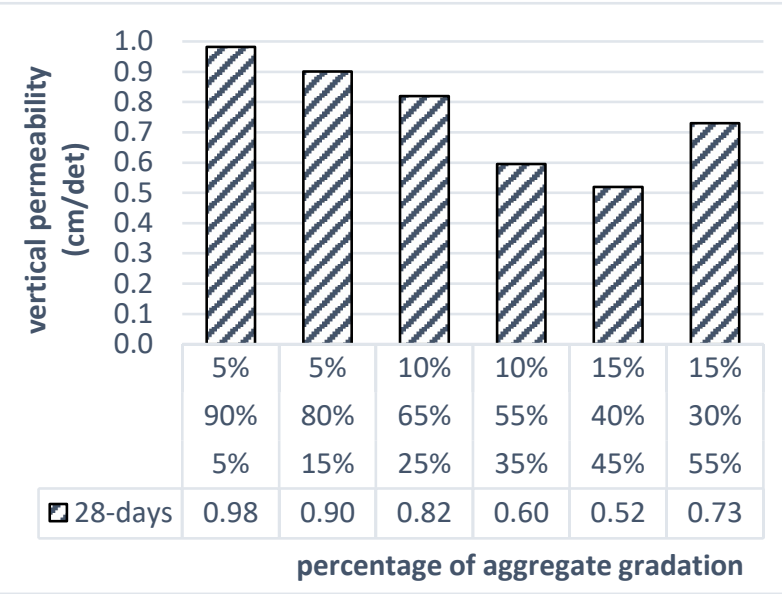

compressive strength: $11.9 \mathrm{MPa}-14.9 \mathrm{MPa}$ void content range: $18.7 \%-24.2 \%$

Fig. 8. Relationship between field gradation variation II and vertical permeability.

\section{Correlation of Basic Property Test Result}

This section covers the result of correlation of basic parameter. Several discussions were attached as well to illustrate the laboratory test result.

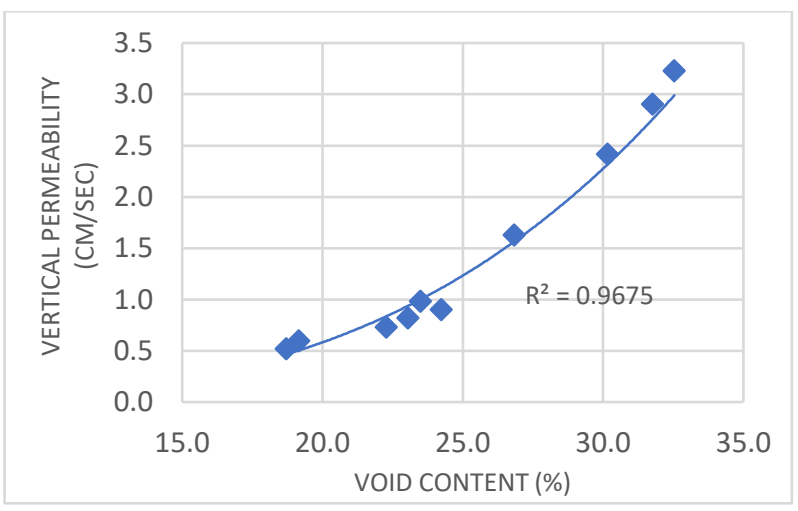

Fig. 9. Correlation between porous concrete void content and permeability at the age of 28-days.

Similar with uniform graded porous concrete, continuous graded porous concrete's vertical permeability owned a direct correlation with its void content at the age of 28-days. Fig. 9 illustrated a dramatic increase from vertical permeability value while the void content was rose. Continuous graded porous concrete also produced a stronger correlation value compared to uniform graded porous concrete which obtained from previous result [9].
Fresh density values from continuous graded porous concrete had a better potency than uniform graded porous concrete when it used as a reference to set the desired porous concrete void content on the field. As can be seen on Fig. 10 and Fig. 11, there were strong negative correlation between fresh density towards void content and permeability at the age of 28-days. These results also showed that continuous graded porous concrete permeability parameter possessed a quite similar behavior with uniform graded porous concrete from the previous test result conducted by Care [7].

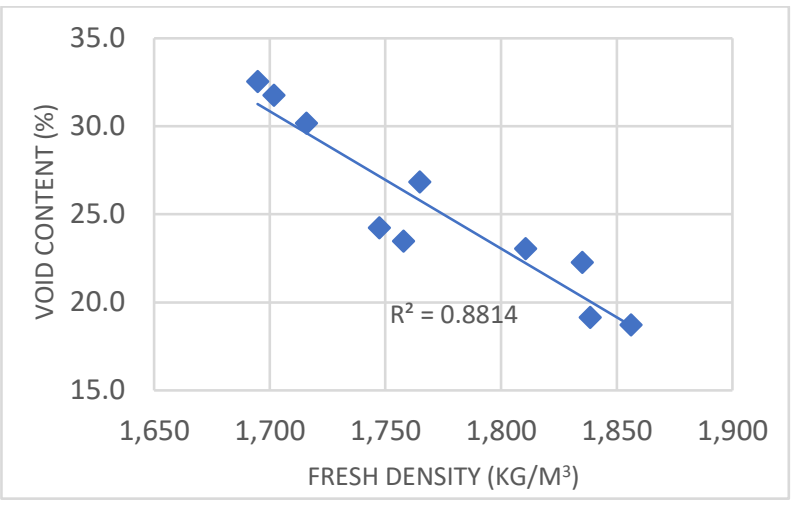

Fig. 10. Correlation between porous concrete fresh density and void content at the age of 28-days.

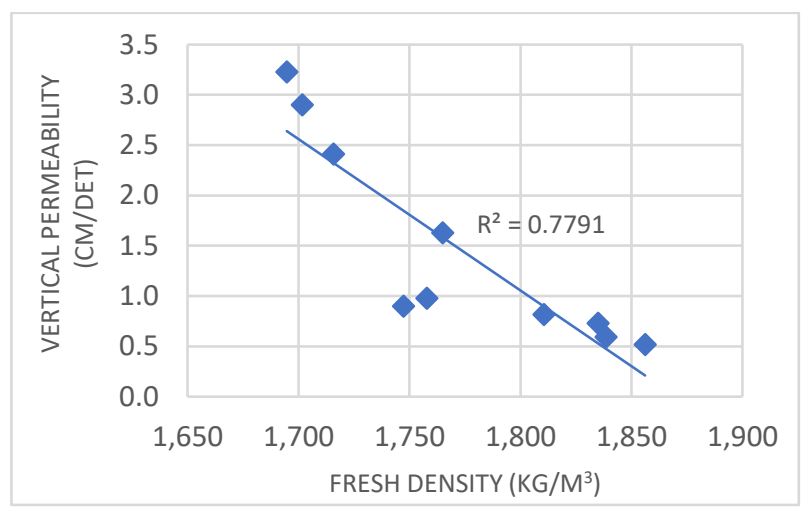

Fig. 11. Correlation between porous concrete fresh density and vertical permeability at the age of 28 -days.

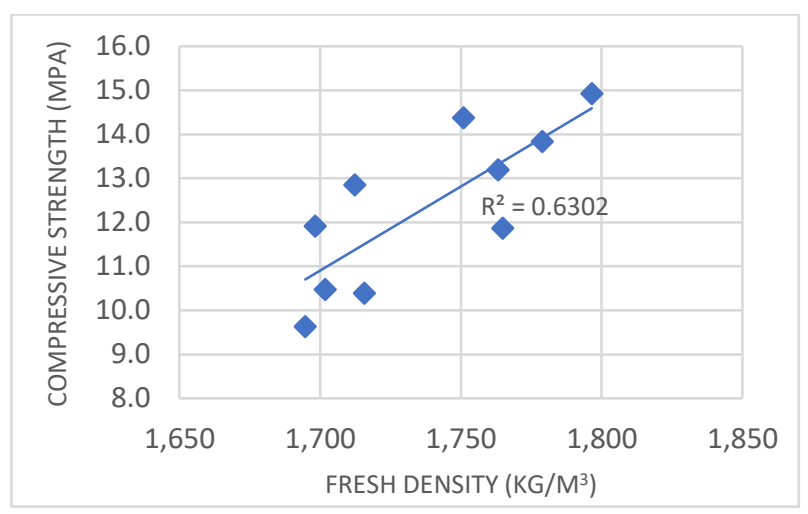

Fig. 12. Correlation between porous concrete fresh density and compressive strength at the age of 28-days.

When compared to the prior result [9], fresh density and void content values from continuous graded porous 
concrete possessed a quite different relationship against its compressive strength. Looking at Fig. 12 and Fig. 13, there were strong correlation between fresh density and void content against compressive strength at the age of 28-days. However, both of correlation values were smaller compared to the correlation value from the uniform graded porous concrete. Cement paste had higher contribution against void amount inside the mixture almost in every uniform graded porous concrete mixproportion. The aggregate interlocking effect could give better contribution against void amount in several continuous graded porous concrete mix-proportion. This situation produced the variety values among basic property parameters so that influenced their correlation value.

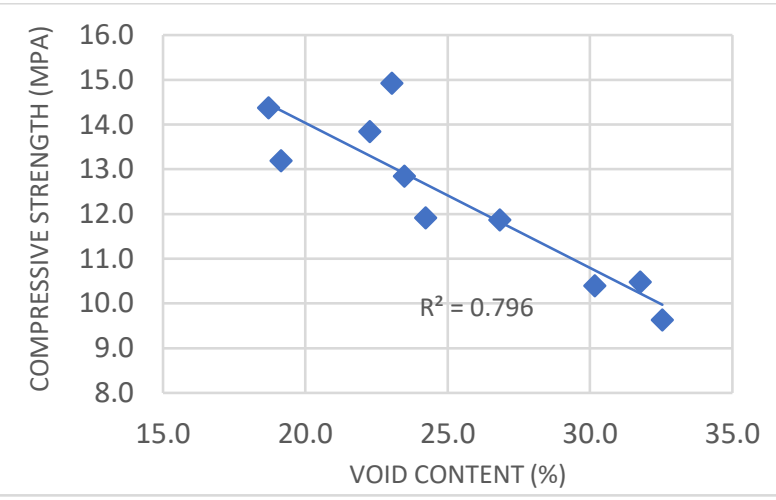

Fig. 13. Correlation between porous concrete void content and compressive strength at the age of 28-days.

\section{Conclusion}

This paper has presented the procedure and result of laboratory experimental study to gain basic property criteria for rigid pavement base layer that adjusting field gradation. Four basic parameters i.e. fresh density, compressive strength, void content and vertical permeability still be used as criteria. The compressive strength and vertical permeability value produced by porous concrete using continuous graded aggregate stayed above the minimum limit for base layer required by Specification. In addition, the compressive strength value had already surpassed the minimum value just at the age of 7-days and only some of void content values lied above $20 \%$ wherein this condition was expected to maintain a high permeability during pavement design life in zero maintenance condition.

Porous concrete that contain continuous graded aggregate possessed low possibility to improve its compressive strength from age 7-days to 28-days. Continuous graded porous concrete from mix-design variation II produced higher compressive strength, but lower void content and vertical permeability compared to mix design variation I at the age of 28-days. It was found that continuous graded porous concrete from both mixdesign variations had an optimum basic parameters in specific value as well. Porous concrete that adjust the field gradation gave a better basic property criterion compared to ideal gradation.
Even though fresh density and void content values from continuous graded porous concrete possessed a quite different relationship against its compressive strength, the relationship between void content and vertical permeability from continuous graded porous concrete had a similar behavior with uniform graded porous concrete. Fresh density values from continuous graded porous concrete also had a better potency than uniform graded porous concrete when it used as a reference to set the desired porous concrete void content on the field. Overall, the use of continuous graded porous concrete would be very helpful in Indonesia because it can adjust the gradation on the field.

The authors thank to PT. Holcim Indonesia Tbk and PT. SIKA Indonesia for their material support and also PT. Nusantara Infrastructure Tbk and Bandung Institute of Technology research program for their financial support.

\section{References}

1. ACI Committee 522, Report on Pervious Concrete, American Concrete Institute (2010)

2. General Specifications $3^{\text {rd }}$ Revision, Directorate General of Highways, Ministry of Public Works (2010)

3. F. A. Kozeliski, Permeable Bases Help Solve Pavement Drainage Problems, the Aberdeen Group, pp. 1-2 (1992)

4. Y. H. Huang, Pavement Analysis and Design, $2^{\text {nd }}$ Edition, Prentice-Hall, Inc. (2004)

5. W. G. Goede, Pervious Concrete: Investigation into Structural Performance and Evaluation of The Applicability of Existing Thickness Design Methods, Master of Science Thesis, Washington State University (2009)

6. G. N. McCain, M. M. Dewoolkar, Porous Concrete Pavements: Mechanical and Hydraulic Properties, TRB 2010 Annual Meeting CD-ROM, University of Vermont (2010)

7. F. R. A. M. Care, B. S. Subagio, H. Rahman, Porous Concrete Basic Property Criteria as Rigid Pavement Base Layer in Indonesia, Proc. MATEC web of Conferences vol. 147, EDP Sciences, pp. 1-16 (2018)

8. F. F. Arnoldus, A. Makmur, Studi Analisa Pengaruh Dimensi Agregat Terhadap Nilai Kuat Tekan dan Tingkat Porositas Air Untuk Beton Berpori Dengan Bahan Tambahan Fly Ash Pada Aplikasi Sidewalk, Jurnal Universitas Bina Nusantara, pp. 1-1 (2011)

9. Manual of Hydraulic for Road and Bridge Works Hydraulic Design, Directorate General of Highways, Department of Public Works, 2005

10. R. C. Meininger, No-Fines Pervious Concrete for Paving, Concrete International Vol. 10 Issue 8 (1998)

11. Anderson, Walsh, Oka, Dewoolkar, Limberg, Sevi, Schmeckpeper, Laboratory Performance of Pervious Concrete Subjected to Deicing Salts and FreezeThaw, University of Vermont Transportation Research Center, pp. 20-20 (2015) 
12. M. I. M. Yusak, R. P. Jaya, M. R. Hainin, C. R. Ismail, M. H. W. Ibrahim, Strength of Porous Concrete Pavement at Different Curing Methods, Jurnal Teknologi, pp. 103-103 (2015)

13. ASTM Standards C39/39M-05, Standard Test Method for Compressive Strength of Cylindrical Concrete Specimens, ASTM International, 2005

14. ASTM Standards D5084-03, Standard Test Method for Measurement of Hydraulic Conductivity of Saturated Porous Materials Using a Flexible Wall Permeameter, ASTM International, 2003

15. ASTM Standards C1688/C1688M-13, Density and Void Content of Freshly Mixed Pervious Concrete, ASTM International, 2013

16. ASTM Standards C1754/C1754M-12, Density and Void Content of Hardened Pervious Concrete, ASTM International, 2012

17. F. Montes, L. Haselbach, Measuring Hydraulic Conductivity in Pervious Concrete, Journal of Environmental Engineering and Science, pp. 968968, 2006

18. E. Lim, T. F. Fwa, K. H. Tan, Laboratory Evaluation of Clogging Behaviour of Pervious Concrete Pavements, Journal of the Eastern Asia Society for Transportation Studies Vol. 11, pp. 1611-1611 (2015) 